\title{
UNCLEAN HANDS: THE EFFECT OF PLAINTIFF'S ANTITRUST VIOLATIONS IN ANTITRUST ACTIONS
}

In Kansas City, an association of employer barbers and the local barbers' union conspired to set minimum prices for haircuts and to fix the hours during which barber shops could remain open. Several employers of union barbers in the area brought a private antitrust action for treble damages ${ }^{1}$ and injunctive relief ${ }^{2}$ against the conspirators. The court noted that the plaintiffs had profited from the fixed prices and operating hours established by defendants, and that the action was precluded by the "unclean hands" doctrine. ${ }^{3}$

In Philadelphia, an association of suburban newspaper distributors sued to enjoin a newspaper publisher from refusing to deal with them. The publisher offered to show that the plaintiffs had been reselling the papers under a price-fixing agreement and claimed that their "unclean hands" should preclude them from maintaining the action. The court said that the plaintiffs' illegal conduct would not defeat the injunction."

The divergent statements in these two recent cases indicate the uncertain state of the unclean hands defense ${ }^{5}$ in private antitrust actions. ${ }^{0}$ And the unfortunate similarity between the cases-the fact that the courts'

138 Stat. 731 (1914), 15 U.S.C. $\$ 15$ (1958).
238 Stat. 737 (1914), 15 U.S.C. $\$ 26$ (1958).

3 Hotel Phillips, Inc. v. Journeymen Barbers Union, 195 F. Supp. 664, 669 (W.D. Mo. 1961) (dictum), aff'd per curiam, 301 F.2d 443 (8th Cir. 1962). The district court based its opinion on a finding that the practices had no effect on interstate commerce. The court of appeals affirmed on that finding.

4 John J. \& Warren H. Graham v. Triangle Publications, Inc., 233 F. Supp. 825 (E.D. Pa. 1964) (dictum). The court held that the unclean hands defense "would not be enough to thwart relief." Id. at 832 . But the defense, added to other facts of the case, would prevent a preliminary injunction.

5 The courts often use the phrases "unclean hands" and "pari delicto" interchangeably. See, e.g., John J. \& Warren H. Graham v. Triangle Publications, Inc., stipra note 4, at 832. Technically, pari delicto is a subdivision of the equitable doctrine of unclean hands. Parties are in pari delicto when both have participated in the same illegal conduct. The unclean hands doctrine covers a variety of situations and applies generally to the plaintiff's illegal or unconscionable conduct. An unclean hands situation which is not pari delicto arises when the plaintiff bases his action on a transaction which is related, though not directly connected, to the plaintiff's own wrongdoing. See Comment, Limiting the Unclean Hands and In Pari Delicto Defenses in Anti-trust Suits: An Additional Justification, 54 Nw. U.L. REv. 456 (1959).

6 This uncertainty also exists in the state courts. Compare Librandi v. Berner's Pharmacy Corp., 2 App. Div. 2d 762, 199 N.Y.S.2d 109 (1960), with Fransca v. Wilson, 23 Misc. 2d 224, 153 N.Y.S.2d 721 (Sup. Ct. 1956). In Librandi one retail druggist brought an action under the state Fair Trade Law for an injunction against another druggist. The defendant claimed that the plaintiff was guilty of the same conduct which he sought to enjoin. The court admitted its reluctance to grant relief to one violating the Fair Trade Law, but stated that the public interest demanded that the defense not be recognized. In Fransca plaintiff brought an action for injunctive relief under the state Fair Trade Law, and the court refused to grant relief when defendant showed that the plaintiff also was violating the same statute. 
interpretation of the doctrine would permit part or all of the restraint of trade to continue-suggests a need for a critical analysis of judicial responses to situations in which both plaintiff and defendant are violating the antitrust laws. This Note will trace the history of the unclean hands defense, analyze the rationales used by the courts in dealing with the defense, and offer suggestions for its future application in private antitrust actions. Many of the underlying policy decisions have been made in cases in which the defense has been raised in actions on contracts for the sale of goods and in actions to protect patent rights. This Note therefore begins with a brief history of the courts' attitude toward the defense in contract and patent actions.

\section{Actions for the Price of Goods}

Actions at law for the price of goods sold were the earliest cases in which a defendant claimed that plaintiff's antitrust violations afforded a defense to the action. However, this defense has been rejected with few exceptions by the courts on the grounds that plaintiff's violations of the antitrust laws do not make the contract illegal and that there is nothing in the antitrust laws which justifies a court in refusing to enforce the antitrust violator's ordinary business contracts.

In the leading case of Connolly v. Union Sewer Pipe Co., ${ }^{7}$ plaintiff brought an action on two promissory notes executed by the defendant on account of the purchase of pipe from the plaintiff. Defendant set up the special defense that plaintiff was a trust in violation of the common law and the Sherman Act ${ }^{8}$ and was a member of a combination formed for the purpose of fixing the price of pipe. The Supreme Court held that even if the combination was illegal, the defense was not available. Although recognizing that "no court will lend its assistance in any way toward carrying out the terms of an illegal contract," ${ }^{9}$ the Court held that the contract between plaintiff and defendant was "collateral" to the illegal combination and that enforcement of the contract would not involve sanctioning the combination..$^{10}$

Seven years later the Supreme Court, following the same "collateral contract" analysis, upheld the defense in Continental Wall Paper Co. $v$. Louis Voight \& Sons. ${ }^{11}$ In that case the leading manufacturers of wall paper formed a corporation to sell their products at identical prices and

7184 U.S. 540 (1902).

826 Stat. 209 (1890), as amended, 15 U.S.C. $\$ \$ 1-7$ (1958).

9 Connolly v. Union Sewer Pipe Co., 184 U.S. 540, 549 (1902).

$10 \mathrm{~A}$ review of the common-law background of the defense and the legislative history of the Sherman Act is given in Lockhart, Violation of the Anti-Trust Lazus as a Defense in Civil Actions, 31 MINN. L. REv. 507 (1947). The author concludes that the failure of Congress expressly to provide for the defense indicates an intention that the courts should determine the scope of the defense rather than that Congress intended to exclude the defense altogether. Id. at 515 .

11212 U.S. 227 (1909). 
required purchasers from the corporation to sign a sales contract fixing the resale price of the paper. ${ }^{12}$ The defendant ordered wall paper under such a contract, but later resisted payment, contending that Continental's violations of the antitrust laws afforded a defense to the action. The Supreme Court, in upholding the defense, distinguished Connolly on the ground that the present contract itself contained an illegal clause, rendering it unenforceable on public policy grounds. Four dissenting Justices, joining in an opinion by Mr. Justice Holmes, argued that the contract should be enforced because there had been a lawful purchase and that the illegal combination did not affect plaintiff's ability to pass title. The dissenting opinion emphasized that "the policy of not furthering the purposes of the trust is less important than the policy of preventing people from getting other people's property for nothing when they purport to be buying it." 13

The Continental decision did not represent a significant shift in the Supreme Court's attitude towards the availability of the defense. A few years later in Wilder Mfg. Co. v. Corn Prods. Ref. Co., ${ }^{14}$ the Court rejected the defense, narrowly limiting Continental to its particular facts-the presence in the sales contract sought to be enforced of a clause violative of the antitrust laws-, and accepted Mr. Justice Holmes' fear of unjustly enriching the defendant as the primary consideration. Thus limited, the Supreme Court's approach in Continental protects only the dissatisfied participants in an unlawful agreement instead of the "victims" 15 of monopoly power. ${ }^{16}$

More recently in Bruce's Juices, Inc. v. American Can Co., ${ }^{17}$ a buyer attempted to base his defense upon the seller's alleged violation of the Robinson-Patman Act. ${ }^{18}$ Defendant, after partial payment, claimed no further liability because of plaintiff's price discrimination against him. The defendant argued alternatively that plaintiff's violations were a complete defense to the action or that the plaintiff's violations limited defendant's liability to the fair market value of the goods. The Supreme Court rejected both arguments in a 5-4 decision. The Court noted that Congress had not provided that antitrust violations should prevent a seller from

12 In 1911 the Supreme Court held that an agreement between a supplier and his distributors designed to maintain resale prices was an unlawful restraint of trade. Dr. Miles Medical Co. v. John D. Park \& Sons, 220 U.S. 373 (1911). (1909).

13 Continental Wall Paper Co. v. Louis Voight \& Sons, 212 U.S. 227, 270-71

14236 U.S. 165 (1915).

15 See Continental Wall Paper Co. v. Louis Voight \& Sons, 212 U.S. 227, 270 (1909) (Holmes, J., dissenting); Lockhart, supra note 10, at 522.

16 In 1906 the defense of illegality was raised in an action to collect the purchase price from the sale of river boats. The contract contained a rate-fixing clause, but the Supreme Court affirmed the state court's dismissal of the defense, finding no interstate commerce. Cincinnati Packet Co. v. Bay, 200 U.S. 179 (1906).

17330 U.S. 743 (1947).

18 The Robinson-Patman Act forbids discrimination in price, services, or facilities between different purchasers of commodities of like grade and quality. 49 Stat. 1526 (1936), as amended, 15 U.S.C. $\$ 13$ (Supp. V, 1964). 
collecting the purchase price for goods and expressed the fear that a decision in defendant's favor would have a disruptive effect on credit transactions. ${ }^{18}$ The Court also advanced a consideration similar to the "collateral" theory used in earlier cases-noting that plaintiff's price discrimination could only be shown by reference to different transactions because the contract itself gave no indication of illegality. ${ }^{20}$

The essential rationale for the decision appears to be the majority's concern that the buyer would be unjustly enriched if he received the goods for nothing. However, they did not see fit to employ the defendant's quantum meruit theory as a means to avoid this injustice. The dissenting Justices, on the other hand, felt that the public interest would have been best served if plaintiff had been permitted to realize only the fair-market value of the goods. They argued that the Court should have been primarily concerned with the result of the judgment-the collection of a discriminatory price. They believed that the absence of a statutory provision for uncollectibility of price was insignificant because of the established common-law principle that the courts will not enforce an illegal contract. ${ }^{21}$

Kelly v. Kosuga, ${ }^{22}$ the most recent Supreme Court decision on this issue, illustrates the limited applicability of the Continental holding. In this case the defendant agreed to purchase onions from the plaintiff as part of a scheme among plaintiff, defendant, and others to withhold delivery of onions on the futures market in order to support the price of onions. ${ }^{23}$ When defendant later refused to take his share of the onions, plaintiff sold them for his account and sued for damages. The defendant claimed that the contract was unenforceable because it was intended to foster an illegal restraint of trade. Because of the posture of the case, the Supreme Court assumed that the agreement not to deliver the onions was illegal and was included in the contract. The Court noted the Continental ${ }^{24}$ decision but held that the contract to buy the onions was divisible from the nondelivery agreement and a legal economic transaction in itself. The Court rejected the defense, holding that the general policy of preventing unjust enrichment would prevail except "where the judg-

19 The Court was also concerned by the fact that the amount of reparation would not be measured by the extent of the injury, but by the amount of credit which the buyer had secured from the seller; the greater the amount of credit, the more the buyer would gain from the defense. The Court thought such a defense would have a "drastic" effect on the economy and noted that the ones most likely to suffer from sellers' hesitancy to give credit would be the small buyers. Bruce's Juices, Inc. v. American Can Co., 330 U.S. 743, 751, 753 (1947).

$20 \mathrm{Id}$. at 755-56.

21 Id. at 761.

22358 U.S. 516 (1959).

23 The Department of Agriculture subsequently suspended the plaintiff's privilege of trading on commodity futures markets. 19 Agri. Dec. 603 (1960).

24 Continental Wall Paper Co. v. Louis Voight \& Sons, 212 U.S. 227 (1909).

The court of appeals had also noted the Continental decision, but said that the case was limited to its "particular vicious facts." Kosuga v. Kelly, 257 F.2d 48, 53 (7th Cir. 1958). 
ment of the Court would itself be enforcing the precise conduct made illegal by the Act . ..." 25

The Kelly decision was recently interpreted by the Sixth Circuit in Associated Press $v$. Taft-Ingalls Corp. ${ }^{26}$ In that case, a member publisher agreed to purchase wire news services for its newspaper from the Associated Press under a contract which provided that the member could terminate the agreement upon two years written notice. When the publisher sold the newspaper, it immediately gave notice to the Associated Press and refused to pay for any further news service. Associated Press sued for the assessments for the two years after the contract was cancelled; the publisher alleged that the contract contained an illegal tying agreement and was void and unenforceable because defendant had been forced to pay for three news wires which it did not desire in order to obtain the news service necessary to its operations.

The district court received evidence on the publisher's defense, but held that there was no tying agreement because the four news wires contained in the contract were not separate products. The court of appeals reversed, and in reply to the contention that Kelly $v$. Kosuga ${ }^{27}$ barred the defense of unlawfulness of contract, distinguished Kelly on the grounds that the plaintiff was claiming damages for services which had never been rendered-thus there was no possibility of unjust enrichment. ${ }^{28}$

In Taft-Ingalls the court was not faced with the divisibility problem present in Kelly because there was no issue of separating a lawful from an unlawful contract provision. However, the case is significant because the court received a great volume of extrinsic evidence to determine whether a contract apparently legal on its face actually contained a tying agreement. This result may have been influenced by the Supreme Court's emphasis in Kelly on determining whether the court is asked to enforce the "precise conduct made unlawful by the Act"; ${ }^{29}$ however, in Kelly the Court used this formulation to narrow rather than to expand the availability of the defense.

The Supreme Court's overt hostility to the defense has resulted in almost incomprehensible distinctions in deciding when a contract sought to be enforced is collateral to the restraint of trade. As the Court itself

25 Kelly v. Kosuga, 358 U.S. 516, 520 (1959). The Court also said that it would enforce the "lawful sale for a fair consideration." Id. at 521. Since the buyer had made no claim that the contract price was unfair, the emphasis on a "lawful sale for a fair consideration" suggests that the defense may be more favorably received when the contract price is not set competitively.

26340 F.2d 753 (6th Cir. 1965).

27358 U.S. 516 (1959).

28 The dissenting judge pointed out that the defendant in Kelly had not received the goods either, and that the suit was for the damages resulting from his refusal to take the goods. He felt that the contract contained no hint of compulsion or illegality and was "'a lawful sale for a fair consideration [which] constitutes an intelligible economic transaction in itself. . . ." Associated Press v. Taft-Ingalls Corp., 340 F.2d 753, 778 (6th Cir. 1965).

29 Kelly v. Kosuga, 358 U.S. 516, 520 (1959). 
recognized in Kelly, attempts to extract a lawful contract from an unlawful scheme of which the contract is an essential element "may well be circular." 30 Furthermore, the Court's approach is unfortunate because a formalistic characterization of a contract as "collateral" to the antitrust violation will often conceal a seller's unfair profiting from a market advantage which the antitrust laws seek to dissipate. This insensitivity is most apparent in Bruce's Juices where the Court rationalized its enforcement of a discriminatory price because of the unreasonableness of declaring all of the seller's contracts unenforceable because of the price differential. ${ }^{31}$ However, the collection of the discriminatory price is precisely what the law forbids. Where a seller seeks to collect such a discriminatory price, the result most consonant with the antitrust laws, while still preventing unjust enrichment, would be to grant recovery only for the fair-market value of the goods. ${ }^{32}$

The courts' refusal to consider antitrust violations may be justifiable by the fear that a recognition of the defense would convert many simple contract suits into complex and protracted antitrust actions. ${ }^{33}$ The Supreme Court has often noted the availability of the treble-damage action and directed dissatisfied buyers toward that remedy. ${ }^{34}$ Although this approach is more convenient for the courts, it cannot justify their enforcement of contracts which enable the plaintiff to benefit from his violations of the antitrust laws. ${ }^{35}$

\section{Patents}

\section{A. Royalties}

Antitrust considerations have also influenced the Supreme Court's rulings in actions for the collection of royalties due under a patent licensing contract. Under the common law, a licensee of a patent is estopped from

\section{$30 \mathrm{Id}$. at 521.}

31 Bruce's Juices, Inc. v. American Can Co., 330 U.S. 743, 754 (1947).

32 See Note, The Defense of Antitrust Illegality in Contract Actions, 27 U. CHr. L. REV. 758 (1955).

33 The burden which antitrust cases place on the courts was recently noted by Judge Wyzanski in United States v. Grinnel Corp., 236 F. Supp. 244, 247 (D.R.I. 1964), in which he said: "This Court is mindful that in recent years antitrust litigation ... [has] involved an enormous, nearly cancerous, growth of exhibits, depositions, and ore temus testimony. Few judges who have sat in such cases have attempted to digest the plethora of evidence, or indeed could do so and at the same time do justice to other litigation in their courts."

34 See, e.g., Bruce's Juices, Inc. v. American Can Co., 330 U.S. 743 (1947) ; D. R. Wilder Mfg. Co. v. Corn Prods. Ref. Co., 236 U.S. 165 (1915).

35 Although the courts have not been disposed to accept the defense, defendants in contract actions have continued to assert it. See, e.g., Aluminum Co. of America v. Tandet, 235 F. Supp. 111 (D. Conn. 1964) ; Ashville Mica Co. v. Commodity Credit Corp., 1963 Trade Cas. f 70786 (S.D.N.Y. 1963); General Elec. Supply Co. v. Fayco Elec. Co., 1962 Trade Cas. II 70312 (N.D.N.Y. 1962). The court in Ashville Mica permitted the defendant to offer proof of the plaintiff's antitrust violations, but held that the defendant had failed to establish the defense as a matter of law. 1963 Trade Cas. I 70921 (S.D.N.Y. 1963). The decision was affirmed on appeal, 335 F.2d 768 (2d Cir. 1964). 
challenging the validity of the patent in a suit for royalties. ${ }^{36}$ However, where the license agreement contains a clause fixing the price of the patented article-an agreement which is per se illegal under the antitrust laws unless the patent is valid ${ }^{37}$-the Supreme Court has held that the policy of enforcing the antitrust laws should override the common-law doctrine of estoppel. Thus, in Sola Elec. Co. v. Jefferson Elec. Co. ${ }^{38}$ a patentee's action for the recovery of unpaid royalties and for an injunction restraining further sales except those made in conformity with the pricemaintenance clause of the license agreement, the Court permitted the defendant to challenge the validity of the patent, stating that local rules of estoppel would not enable the plaintiff to enforce an agreement which may be violative of the antitrust laws.

The Court later reaffirmed this principle in Edward Katzinger Co. v. Chicago Metallic Mfg. Co. ${ }^{39}$ where the patentee, in a suit for a declaratory judgment of noninfringement, counterclaimed for royalties due under a license which contained a price-fixing agreement. The patentee attempted to distinguish Sola because he did not ask the Court to enforce the pricefixing agreement since the license had terminated. However, the Supreme Court held that the licensee was not estopped from challenging the validity of the patent. The Court interpreted Sola as "firmly grounded upon the broad public interest in freeing our competitive economy from the trade restraints which might be imposed by price-fixing agreements stemming from narrow or invalid patents." 40

Although the principal issue in these cases was whether the commonlaw estoppel doctrine should be applied, the cases can be analyzed as part of the much larger framework of the use of plaintiff's violations of the antitrust laws as a defense to a suit upon a contract. Viewed in this context, they are consistent with the Continental decision ${ }^{41}$ because the courts did not have to go outside the terms of the contract to determine whether there had been an unlawful restraint of trade. However, the cases are significant in that the policy of full enforcement of the antitrust laws was held to justify a full trial hearing on the complicated issue of the validity of a patent-thus protracting an otherwise simple contract action.

Moreover, in patent cases the Supreme Court has shown a greater reluctance to hold that part of an agreement is "collateral" to the antitrust

36 MacGregor y. Westinghouse Elec. \& Mfg. Co., 329 U.S. 402, 408 (1947) (Frankfurter, J., dissenting); Sola Elec. Co. v. Jefferson Elec. Co., 317 U.S. 173 (1942); United States v. Harvey Steel Co., 196 U.S. 310 (1905); Kinsman v. Parkhurst, 59 U.S. (18 How.) 289 (1856).

37 See, e.g., Edward Katzinger Co. v. Chicago Metallic Mfg. Co., 329 U.S. 394 (1947); Sola Elec. Co. v. Jefferson Elec. Co., 317 U.S. 173, 175-76 (1942).

38317 U.S. 173 (1942).

39329 U.S. 394 (1947). (1947).

40 Id. at 400. See also MacGregor v. Westinghouse Elec. \& Mfg. Co., 329 U.S. 402

41 Continental Wall Paper Co. v. Louis Voight \& Sons, 212 U.S. 227 (1909). 
violation and is thus enforceable. The Court's rationale in Katzinger for holding the price-fixing clause not severable from the agreement to pay royalties because they "constituted an integrated consideration for the license grant" ${ }^{42}$ was not accepted in Kelly $v$. Kosuga, ${ }^{43}$ where the seller's agreement not to unload his onions on the market was certainly the essential consideration for the buyer's agreement to purchase.

\section{$B$. Infringement}

In patent infringement cases the courts have not adhered to the restrictions on the defense of plaintiff's antitrust violations which have been applied in actions for the price of goods. In these cases, the courts have been willing to look beyond the conduct which gives rise to the action in order to determine what effect a decree for plaintiff will have on the competitive situation.

In the landmark case of Morton Salt Co. v. G. S. Suppiger Co., ${ }^{44}$ the plaintiff, a leading canner of food products, alleged infringement of its patent on a machine for depositing salt tablets in cans and prayed for an injunction and for an accounting of the profits realized from the infringement. The defendant's deposition evidence showed that the plaintiff was using his patent in restraint of trade by requiring, as a condition of its leasing agreements, that the users of the machine purchase plaintiff's unpatented salt tablets. The trial court granted summary judgment for the defendant. The Supreme Court affirmed, holding that the maintenance of the action was contrary to public policy and was rightly dismissed-irrespective of whether plaintiff's tying agreements actually violated the antitrust laws. The lower federal courts, in applying the Morton Salt holding, have similarly held that a violation of the antitrust statutes need not be shown for the court to deny relief. ${ }^{45}$

Perhaps the basic policy consideration underlying the Supreme Court's decision to deny relief for infringement is that a patent grants a statutory monopoly which is inconsistent with our basic theory of free enterprise, and the courts take all means available to prevent the patentee from abusing the market power which the patent provides. ${ }^{46}$ Thus, when the patentee

42 Edward Katzinger Co. v. Chicago Metallic Mfg. Co., 329 U.S. 394, 401 (1947).

43358 U.S. 516 (1959).

44314 U.S. 488 (1942).

45 See, e.g., Berlenbach v. Anderson \& Thompson Ski Co., 329 F.2d 782, 784 (9th Cir. 1964); Waco-Porter Corp. v. Tubular Structures Corp., 222 F. Supp. 332, 334 (S.D. Cal. 1963). The Supreme Court's holding in Morton Salt was limited to a ruling that a patentee is precluded from bringing an action for infringement until he shows that the misuse of the patent has been discontinued and that the effects of misuse have been purged. The opinion thus left open the question whether the patentee could recover damages for the infringement during the period of misuse after he had purged himself. A recent case makes clear that there can be no recovery for damage during the time of misuse, even after the patentee purges himself. Preformed Line Prods. Co. v. Fanner Mfg. Co., 328 F.2d 265, 279 (6th Cir. 1964).

46 See Sears, Roebuck \& Co. v. Stiffel Co., 376 U.S. 225, 229-30 (1964) ; Morton Salt Co. v. G. S. Suppiger Co., 314 U.S. 488 (1942) ; Ethyl Corp. v. Hercules Powder Co., 232 F. Supp. 453 (D. Del. 1963). 
uses the patent to restrain competition in a manner not justified by the purposes of granting the limited monopoly, the patentee's rights under the patent will not be protected by judicial action. Significantly, the judicial creation of this defense-which denies the patentee all protection for his invention-developed without legislative guidelines, and the courts were noticeably less restrained in extending the antitrust defense than they were in actions for the price of goods. ${ }^{47}$

But another important consideration in the Morton Salt decision was the traditional reluctance of courts of equity to aid those who come into the court with unclean hands. ${ }^{48}$ This equitable doctrine is based on the policy that the integrity of the courts must be maintained by denying relief where such relief would further plaintiff's unlawful purpose; the doctrine is not usually considered a protection for the defendant, but a means of protecting a court of conscience. ${ }^{49}$ However, the Court in Morton Salt did admit that "equity does not demand that its suitors shall have led blameless lives"; ${ }^{50}$ the effect of the relief demanded must be balanced against the seriousness of the plaintiff's anticompetitive practices. In most of the cases, the balancing has resulted in a decision in favor of enforcing the antitrust laws by denying relief to a patentee who is shown to be using his patent to restrain trade. ${ }^{51}$

\section{The Defense in Antitrust Actions}

When plaintiff's antitrust violations are claimed as a defense in a private action for treble damages ${ }^{52}$ or an injunction ${ }^{53}$ under the antitrust laws, the courts are faced with a more complex problem in shaping their

47 See, e.g., Wilder Mfg. Co. v. Corn Prods. Ref. Co., 236 U.S. 165 (1915).

48 See Morton Salt Co. v. G. S. Suppiger Co., 314 U.S. 488, 492 (1942) ; Ethyl Corp. v. Hercules Powder Co., 232 F. Supp. 453, 458 (D. Del. 1963). Compare Gaudiosi v. Mellon, 269 F.2d 873 (3d Cir. 1959).

49 Gaudiosi v. Mellon, supra note 48.

50 Morton Salt Co. v. G. S. Suppiger Co., 314 U.S. 488, 493 (1942).

51 See, e.g., Mercoid Corp. v. Mid-Continent Inv. Co., 320 U.S. 661 (1944); Berlenbach v. Anderson \& Thompson Ski Co., 329 F.2d 782 (9th Cir. 1964); WacoPorter Corp. v. Tubular Structures Corp. of America, 222 F. Supp. 332 (S.D. Cal. 1963). Compare Preformed Line Prods. Co. v. Fanner Mfg. Co., 328 F.2d 265 (6th Cir. 1964).

52 Any person who shall be injured in his business or property by reason of anything forbidden in the antitrust laws may sue therefor in any district court of the United States in the district in which the defendant resides or is found or has an agent, without respect to the amount in controversy, and shall recover threefold the damages by him sustained, and the cost of suit, including a reasonable attorney's fee.

38 Stat. 731 (1914), 15 U.S.C. \$ 15 (1958).

53 Any person, firm, corporation, or association shall be entitled to sue for and have injunctive relief, in any court of the United States having jurisdiction over the parties, against threatened loss or damage by a violation of the antitrust laws... when and under the same conditions and principles as injunctive relief against threatened conduct that will cause loss or damage is granted by courts of equity, under the rules governing such proceedings . . .

38 Stat. 737 (1914). 15 U.S.C. \$26 (1958). 
attitudes towards the defense in order to promote the most effective enforcement of the antitrust laws. On the one hand, the courts have recognized that private suits against violators play a vital role in the promotion of competition. ${ }^{54}$ Thus, it is not surprising that the courts have been reluctant to discourage private actions by holding that plaintiffs' own antitrust violations are a bar to recovery. On the other hand, sound law enforcement does not lightly countenance a plaintiff profiting from a statutory cause of action derived from the same regulations which the plaintiff himself has violated.55 Unfortunately, the courts' resolution of this conflict has given too little attention to the underlying policy of the antitrust laws-the encouragement of competition. This section of the Note will analyze the underlying rationales of the judicial decisions in this area and suggest an approach most compatible with the goal of eliminating anticompetitive activities.

\section{A. Treble Damage Actions}

The most effective deterrent against violations of the antitrust laws is the private action for treble damages. ${ }^{56}$ The recoveries which may be awarded in these civil actions often amount to such amazing sums ${ }^{57}$ that it is not surprising that defendants have claimed that the plaintiff's own violations of the antitrust laws preclude him from bringing the action.

In Kiefer-Stewart Co. v. Joseph E. Seagram \& Sons, Inc., ${ }^{58}$ a wholesaler of liquor brought suit for treble damages against certain distillers who had conspired to sell liquor only to those wholesalers who agreed not to resell above a fixed maximum price. As part of their defense, the distillers offered evidence to prove that the plaintiff had conspired with other wholesalers to set minimum prices for the retail sale of liquor. At the conclusion of the evidence, the trial court charged the jury that a violation of the antitrust laws by the plaintiff would be no defense to the treble-damage action, and the Supreme Court upheld the correctness of the charge on the grounds that: "the alleged illegal conduct of petitioner . . . could not legalize the unlawful combination by respondents nor immunize them against liability to those they injured." 59

Since Kiefer-Stewart, the fact that the plaintiff is an antitrust violator in an unrelated transaction has met with little success as a defense in a

54 See, e.g., J. I. Case Co. v. Borak, 377 U.S. 426, 432 (1964) ; Lawlor v. National Screen Serv. Corp., 349 U.S. 322, 329 (1955) ; Monarch Life Ins. Co. v. Loyal Protective Life Ins. Co., 326 F.2d 841, 845 (2d 'Cir. 1963), cert. denied, 376 U.S. 952 (1964). Compare 110 Cong. Rec. 3140-41 (1964) (remarks of Senator Humphrey).

55 See, e.g., Fransca v. Wilson, 23 Misc. 2d 224, 153 N.Y.S.2d 721 (Sup. Ct. 1956). 5638 Stat. 731 (1914), 15 U.S.C. $\S 15$ (1958).

57 It has been estimated that it will cost General Electric over $\$ 160,000,000$ to settle the treble damage suits arising from its conviction of price fixing. Note, 112 U. PA. L. Rev. 1133, 1134 (1964).

58340 U.S. 211 (1951).

$59 I d$. at 214. 
treble-damage action. Three years later, in Moore v. Mead's Fine Bread Co., ${ }^{60}$ the Supreme Court reaffirmed Kiefer-Stewart in holding that the plaintiff's promotion of a boycott of defendant's products would not justify defendant's response of discriminatory prices. The lower courts have used Kiefer-Stewart and Moore as authority for refusing to allow defendants to exculpate themselves completely through the plaintiff's antitrust violations. ${ }^{\text {61 }}$

However, the lower federal courts have not extended the KieferStewart rule to cases in which the plaintiff and defendant have been involved in the same illegal scheme. Soon after Kiefer-Stewart a pari delicto defense was accepted in a treble-damage action by the Fourth Circuit in Pennsylvania Water \& Power Co. v. Consolidated Gas Elec. Light \& Power $\mathrm{Co}^{62}$ In that case, the plaintiff and defendant had entered into an illegal agreement in restraint of trade under which each agreed not to construct new facilities without the consent of the other. When plaintiff sought to build additional facilities, the defendant refused to grant its permission, and the plaintiff was forced to resort to litigation to have the contract declared illegal and unenforceable. ${ }^{63}$ The plaintiff then sued for treble damages based upon the lost profits and the increased construction costs from the delay caused by the court action, but the defendant argued that plaintiff's involvement in the restraint of trade precluded him from recovering under the antitrust laws. The court distinguished KieferStewart on the ground that the plaintiff there had not been a party to the illegal agreement which formed the basis of the suit, and on this distinction it reasoned that the Supreme Court in Kiefer-Stewart had not intended to overrule the well-established pari delicto doctrine.

Although the Pennsylvania Water \& Power case has been followed by other courts, ${ }^{64}$ the Supreme Court has never passed upon the issue. Moreover, the lower courts have narrowly restricted the use of the pari delicto defense. It will not prevail when the plaintiff has been forced into the illegal combination by economic coercion ${ }^{65}$ or other illegal practices by the defendant. ${ }^{66}$

60348 U.S. 115 (1954).

61 See, e.g., Bales v. Kansas City Star Co., 336 F.2d 439, 444 (8th Cir. 1964); Union Leader Corp. v. Newspapers of New England, Inc., 284 F. 2d 582, 586 (1st Cir. 1960), cert. denied, 365 U.S. 813 (1961); Budget Dress Corp. v. IlGWU, 25 F.R.D. 506 (S.D.N.Y. 1959).

62209 F.2d 131 (4th Cir. 1953), cert. denied, 347 U.S. 960 (1954).

63 Pennsylvania Water \& Power Co. v. Consolidated Gas, Elec. Light \& Power Co., 186 F.2d 934 (4th Cir. 1951).

64 See, e.g., Bales v. Kansas City Star Co., 336 F.2d 439, 444 (8th Cir. 1964); Kershaw v. Kershaw Mfg. Co., 209 F. Supp. 447 (M.D. Ala. 1962); Lehmann Trading Corp. v. J \& H Stolow, Inc., 184 F. Supp. 21 (S.D.N.Y. 1960).

65 See, e.g., Jewel Tea Co. v. Associated Food Retailers, 331 F.2d 547 (7th Cir.), cert. granted, 379 U.S. 813 (1964) ; Peter v. Western Newspapers Union, 200 F.2d 867 (5th Cir. 1953); Farbenfabriken Bayer, A.G. v. Sterling Drug, Inc., 197 F. Supp. 627 (D.N.J. 1961).

66 Union Leader Corp. v. Newspapers of New England, Inc., 284 F.2d 582, 586-87 (1st Cir. 1960). 
The judicial decisions in this area are supportable on several policy grounds, the most important being the need to encourage private actions under the antitrust laws. In view of the time and expense necessary to bring a private treble-damage action, an additional obstacle would only serve to lessen the effectiveness of the remedy. Thus, if the private plaintiff who has been injured by an antitrust violation is regarded essentially as representing the public interest in deterring such violations, the plaintiff's unrelated violations should not, in most instances, bar recovery. On the other hand, the pari delicto defense should be accepted because the public interest would best be served by deterring those who are tempted to enter an illegal combination with the expectancy of collecting treble damages if they are injured because of the agreement. The problem of complicating the case with evidence of unrelated antitrust violations does not exist when the pari delicto defense is claimed, because the defendants are not attempting to show other than that the plaintiff was involved in the same unlawful combination. ${ }^{67}$

Thus far, this analysis would produce results similar to those which obtain in actions for the price of goods, where the courts refuse to look beyond the particular contract ${ }^{68}$-or, in this context, the transactions which constitute the defendant's alleged antitrust violations-to determine whether the plaintiff should be barred from recovering. However, this similiarity does not justify a similar judicial response to the defense because the antitrust policy considerations militate toward accepting the defense in certain situations. Where the ability to obtain a treble-damage recovery would directly protect a plaintiff's unlawful practices, recovery should be denied, not as an ad hoc judicial punishment for the plaintiff's wrongdoing, but as a recognition that the public interest would best be served by refusing to entertain the action.

\section{B. Actions for Injunctive Relief}

The public policy rationales which the courts have used in trebledamage actions to reject defenses based upon the plaintiff's antitrust violations apply with equal vitality to suits for injunctions. ${ }^{69}$ Indeed, the public interest may be of greater significance in the latter situation because a court of equity has the power to dissipate the anticompetitive effects of an antitrust violation. It is therefore not surprising that the courts have

${ }^{67}$ See Comment, Limiting the Unclean Hands and In Pari Delicto Defenses in Anti-trust Sutits: An Additional Justification, 54 Nw. U.L. REv. 456 (1959).

No cases have been found in which the plaintiff was bringing the treble-damage action with the aid of a prior government-obtained conviction. A judgment in favor of the United States in any civil or criminal proceeding under the antitrust laws is prima facie evidence in any action brought by a private party. 38 Stat. 731 (1914), 15 U.S.C. $\$ 16$ (1958). The defendant in a civil action brought with the aid of $\$ 16$ should be permitted to offer evidence that the plaintiff was in pari delicto for the same reasons that the defense is permissible in any other civil suit.

68 See text accompanying notes 14-16 sipra.

6938 Stat. 737 (1914), 15 U.S.C. $\$ 26$ (1958). 
assumed a hostile attitude toward the defense in actions for injunctions. However, the courts have failed in their avowed purpose of effectively enforcing the antitrust laws by uncritically accepting the rules which have been developed at law.

The question whether a plaintiff's unclean hands due to antitrust violations constitutes a defense to an action for an injunction is still not settled because the Supreme Court has never passed upon the issue. A leading lower court decision is Trebuhs Realty Co. v. News Syndicate Co. ${ }^{70}$ In Trebuhs, the owners of several theaters in New York City sued to restrain publishers of local newspapers from refusing to sell them amusement advertising space and from refusing to sell them such space at rates which other purchasers of the same quantity were granted. The defendants alleged that the plaintiffs had combined to monopolize the booking of plays in New York City and to control the advertising for the plays by requiring the producers to advertise only through agencies designated by the plaintiffs. They claimed as affirmative defenses that the plaintiffs were precluded from bringing the action because of the doctrine of unclean hands, and that a decree in equity in plaintiffs' favor would aid a conspiracy violative of the antitrust laws by strengthening plaintiffs' control over producers of legitimate plays. The court granted the plaintiffs' motion to strike the defense, concluding that the Supreme Court's decisions in Kiefer-Stewart ${ }^{71}$ and Moore ${ }^{72}$ showed a "clear trend toward the abolition of the defense of 'unclean hands' in antitrust violation suits." 73 The court noted that these cases were at law, but felt that the Supreme Court's recognition of the preeminence of the policy of enforcing the antitrust laws applied with equal strength to actions in equity. In response to the defendants' assertion that a decree in plaintiffs' favor would aid them in perpetuating their monopoly, the court answered that the defendants could counterclaim or bring their own suit for relief 74 and that the possibility of relief by Government action also existed. The court felt that if the defendants' unclean hands defense was accepted, both parties would be free to continue their illegal activities and the public interest would suffer.

Three months later, the same court faced a similar issue in Interborough News Co. v. Curtis Publishing Co. ${ }^{75}$ In that case, certain

70107 F. Supp. 595 (S.D.N.Y. 1952).

71 Kiefer-Stewart Co. v. Joseph E. Seagram \& Sons, 340 U.S. 211 (1951).

72 Moore v. Mead Serv. Co., 340 U.S. 944 (1951). 1952).

73 Trebuhs Realty Co. v. News Syndicate Co., 107 F. Supp. 595, 599 (S.D.N.Y.

74 The possibility of the defendants' bringing a separate suit for relief may not be too great. The defendants may not be damaged by the plaintiff's restraint of trade, and, if the charge cannot be used as a defense in the action, there will be no incentive to bring the plaintiff's antitrust violations before the court. Thus, the court will lose the opportunity to alleviate the effects of plaintiff's restraint of trade. See Haverhill Gazette Co. v. Union Leader Corp., 333 F.2d 798 (1st Cir. 1964).

75108 F. Supp. 768 (S.D.N.Y. 1952). 
publishers of magazines and paperback books who allegedly boycotted the plaintiff, a wholesale distributor of periodicals, defended an action for treble damages and injunctive relief on the grounds that the plaintiffs had unlawfully sought to acquire and perpetuate a monopoly by eliminating the other wholesale distributors in the New York City area. The court peremptorily struck the unclean hands defense on the ground that KieferStervart, ${ }^{76}$ Moore, ${ }^{77}$ and Trebuhs ${ }^{78}$ had almost completely abolished it.

Since Interborough, most courts have regularly denied the unclean hands defense in actions for injunctive relief under the antitrust laws. ${ }^{79}$ However, the equity courts have continued to apply the rules developed at law by accepting the pari delicto defense in actions for injunctive relief. One example of this approach is Lehmann Trading Corp. v. $J \& H$ Stolow, Inc., ${ }^{80}$ decided by the same court which decided Trebuhs and Interborough. In Lehmann, the plaintiffs, agents for certain foreign governments for the sale of stamps to collectors, sought an injunction and treble damages from several stamp dealers who conspired to compel the plaintiffs to grant them discriminatorily lower prices. The dealers interposed the pari delicto doctrine as an affirmative defense, claiming that the plaintiffs had participated in and benefited from the price discrimination scheme. The Court denied the plaintiffs' motion to strike the defense. It recognized that the use of the unclean hands defense in antitrust actions had been greatly restricted but held, relying on Pennsylvania Water \& Power $^{81}$ and other actions for treble damages, ${ }^{82}$ that the pari delicto defense would still prevail.

The indiscriminate acceptance of the pari delicto doctrine is the most striking example of the failure to provide for effective enforcement of the antitrust laws. Acceptance of the doctrine in actions for treble damages serves the public interest because it may deter businessmen from entering into unlawful conspiracies. Its acceptance in actions for injunctions, however, denies the court an opportunity to protect the public from the continuance of unlawful practices. Yet the courts forego this opportunity in the ideal situation in which the plaintiff seeks to break up a conspiracy, all the facts of which he has full knowledge. The only explanation for this approach must be the courts' reluctance to aid a wrongdoer when he

76 Kiefer-Stewart Co. v. Joseph E. Seagram \& Sons, 340 U.S. 211 (1951).

77 Moore v. Mead Serv. Co., 340 U.S. 944 (1951).

78 Trebuhs Realty Co. v. News Syndicate Co., 107 F. Supp. 595 (S.D.N.Y. 1952). 79 See, e.g., McKesson \& Robbins, Inc. v. Charles Pfizer \& Co., 235 F. Supp. 743 (E.D. Pa. 1964); John J. \& Warren H. Graham v. Triangle Publications, Inc., 233 F. Supp. 825 (E.D. Pa. 1964); Interborough News Co. v. Curtis Publishing Co., 108 F. Supp. 768 (S.D.N.Y. 1952).

80184 F. Supp. 21 (S.D.N.Y. 1960).

81 Pennsylvania Water \& Power Co. v. Consolidated Gas, Elec. Light \& Power Co., 209 F.2d 131 (4th Cir. 1953), cert. denied, 347 U.S. 960 (1954).

${ }^{82}$ H. \& A. Selmer, Inc. v. Musical Instrument Exch., 154 F. Supp. 697 (S.D. N.Y. 1957) ; New York Credit Men's Adjustment Bureau v. Bruno-New York, Inc., 120 F. Supp. 495 (S.D.N.Y. 1954). 
becomes dissatisfied with his illegality, but this rationale has no place in antitrust suits, where the equities between the parties must be subordinated to the public interest. 83

However, where plaintiff and defendant are not involved in the same unlawful scheme, other considerations militate toward a more liberal acceptance of the "unclean hands" defense in actions for injunctions. The fundamental objection to the wholesale adoption of the principles developed at law is that it fails to recognize the function of courts of equity as expressed in section 16 of the Clayton Act:

[A] ny person ... shall be entitled to ... injunctive relief . . against threatened loss or damage by a violation of the antitrust laws . . . when and under the same conditions and principles as injunctive relief against threatened conduct that will cause loss or damage is granted by courts of equity, under the rules governing such proceedings .... ${ }^{84}$

The legislative history of the act reveals that Congress was not concerned with any particular defense when it included the reference to the rules of equitable proceedings. ${ }^{85}$ Since the "unclean hands" defense was well established at the time of passage of the Clayton Act, ${ }^{86}$ courts should not thwart the legislative intent by accepting the defense in actions for injunctions when they decide it would serve the public interest. The "unclean hands" doctrine developed in equity as a vehicle by which courts of conscience were able to withhold their extraordinary relief from "a suitor who in the very controversy has so conducted himself as to shock the moral sensibilities of the judge." 87 In determining whether they

83 Compare Hotel Phillips, Inc. v. Journeymen Barbers Union, 195 F. Supp. 664 (W.D. Mo. 1961), aff'd per curian, 301 F.2d 443 (8th Cir. 1962), in which the plaintiffs charged the defendants with fixing the prices and hours of barber shops in the metropolitan Kansas City area. The complaint was dismissed because the effect on interstate commerce was too indirect and inconsequential to support an action under the antitrust laws. However, in the course of its opinion, the court noted that the plaintiffs charged the same prices and kept the same hours as the defendants, and therefore had unclean hands and were in no position to maintain the private antitrust action. The court of appeals expressly did not rule on the clean hands statement. 301 F.2d at 445 . If the requisite interstate commerce had been found, and plaintiffs' unclean hands precluded relief, the decision would have left the public to suffer under the price-fixing conspiracy because the plaintiffs had once engaged in it.

8438 Stat. 737 (1914), 15 U.S.C. \$26 (1958). (Emphasis added.)

85 A reading of the Congressional Record shows that Congress was greatly concerned at the time of passage of the section with the abuse of the equitable powers in cases concerning labor disputes. See, e.g., 51 CoNG. REc. 9610-11 (1914) (remarks of Representative Floyd); 51 CoNG. REC. 9655 (1914) (remarks of Representative Buchanan). Therefore, the reference to the traditional rules governing proceedings in equity may have been inserted in the statute to alleviate the fears of those who were concerned with the danger of "government by injunction." Compare 51 Cong. REc. 14367 (1914) (remarks of Senator Borah).

86 See Keeton, An Introduction to EQuity 142 (4th ed. 1956); Chafee, Coming Into Equity With Unclean Hands, 47 Mich. L. Rev. 877, 880 (1949).

87 Art Metal Works, Inc. v. Abraham \& Straus, Inc., 70 F.2d 641, 646 (2d Cir.) (L. Hand, J., dissenting), cert. denied, 293 U.S. 596 (1934). 
could fairly come to plaintiff's aid, the courts would balance against the guilt of the defendant, the culpability of the plaintiff's conduct either toward the defendant or toward others where an injury similar to that asserted by plaintiff was involved. If the public interest in eliminating restraints on competition is substituted for the relative guilt of the plaintiff, then this balancing process is particularly suited to antitrust litigation.

This fashioning of private relief to effectuate a public policy is not unknown to courts of equity. As the Supreme Court recognized in Morton Salt: "It is a principle of general application that courts, and especially courts of equity, may appropriately withhold their aid where the plaintiff is using the right asserted contrary to the public interest." 88 And the difficulties of further protracting the litigation by hearing another antitrust charge-which did not deter the Supreme Court in the patent infringement cases ${ }^{80}$-are compensated by the courts' ability to relieve the most serious restraints on competition.

However, one of the few courts to consider the seriousness of a plaintiff's antitrust violations in a suit for injunctive relief reached a result contrary to the public interest. In Louisiana Petroleum Retail Dealers, Inc. v. Texas Co., ${ }^{90}$ several independent gasoline dealers sought an injunction restraining three national oil companies and their local dealers from fixing the retail price of gasoline. The defendants offered evidence that the plaintiffs had conspired to fix retail prices in the same area in order to alleviate the effects of gasoline price wars. The court decided that the equitable doctrine of unclean hands was available under section 16 of the Clayton Act and held that the plaintiffs were guilty of the same conduct with which they charged the defendants. The court dismissed the suit because a decree in plaintiffs' favor would assist them in their own price-fixing activities. ${ }^{91}$

The court's mishandling of the "unclean hands" defense is apparent. By applying its rationale of refusing to aid an equally-guilty plaintiff, the court allowed the parties to continue their price-fixing schemes. If the court had based its analysis on the public interest instead of the relative equities of the parties, it would have recognized that competition would have been fostered by enjoining the defendants' activities, because a resumption of free competition among these retailers might have forced a dissolution of the plaintiffs' conspiracy. ${ }^{92}$

88 Morton Salt Co. v. G. S. Suppiger Co., 314 U.S. 488, 492 (1942).

89 See text accompanying notes $41-42$ supra.

90148 F. Supp. 334 (W.D. La. 1956).

91 The court specifically relied upon reference in the act to the "rules governing equitable proceedings" and asserted that the well established unclean hands defense precluded any relief.

92 See also John J. \& Warren H. Graham v. Triangle Publications, Inc., 233 F. Supp. 825 (E.D. Pa. 1964), in which the plaintiff sought an injunction to force the defendant to furnish him with newspapers. The defendant claimed that the plaintiff was selling the papers under a price-fixing scheme. The court said that 
Moreover, the court in Louisiana Petroleum failed to utilize one of the most valuable attributes of a court of equity, its flexibility in shaping its decrees. $^{93}$ This flexibility enables equity courts to avoid the rigidity of the all-or-nothing approach which the law courts have developed toward the defense. Thus, in a suit for an injunction, the court has within its discretion the power to deny relief until the plaintiff has ceased his unlawful practices or to condition relief on the performance of certain remedial acts by the plaintiff.94

The ability of a court of equity to decree conditional relief may be a most important judicial device in the preservation of free competition because it enables a court to cure two antitrust violations in a single action. For, where an injunction would directly aid the plaintiff's antitrust violation, the courts could require the plaintiff to discontinue his unlawful practices as a condition for obtaining relief against the defendant's activities. And, the plaintiff's desire to avoid further injury from the defendant would encourage him to observe the conditional decree.

\section{A Suggested Approach}

It is almost always true that if the plaintiff is also an antitrust violator, any relief from the defendant's anticompetitive restraints will enhance the plaintiff's market position and make his abuse of that position more effective. However, the public interest in encouraging private enforcement of the antitrust laws necessarily limits the instances in which the courts should entertain the allegation that plaintiff's violations of the antitrust laws preclude relief. If all plaintiffs who are violating the antitrust laws are discouraged from bringing private actions, many serious violations may go uncorrected without any compensating public benefit, because most plaintiffs would be able to continue their own violations irrespective of whether they obtain relief from the defendant. Therefore the courts should eliminate the defendant's anticompetitive practices unless it is clear that the public would be directly benefited by denying relief to the plaintiff or by conditioning relief upon termination of the plaintiff's violations. Only in situations where it is unlikely that the plaintiff would be able to continue his unlawful practices without obtaining the desired relief should the defense be entertained, because in these cases a decree in the plaintiff's favor would only permit him instead of the defendant to victimize the public.

the defense would not preclude the action. The injunction was denied on other grounds, but if the other grounds had not been present, the court would have been in the position whereby it would order the defendant to furnish the plaintiff with goods which the plaintiff would then sell under an illegal price-fixing scheme.

93 "Traditionally, equity has been characterized by a practical flexibility in shaping its remedies and by a facility for adjusting and reconciling public and private needs." Brown v. Board of Educ., 349 U.S. 294, 300 (1955).

94 "A court of equity may in its discretion in the exercise of the jurisdiction committed to it grant or deny relief upon performance of a condition which will safeguard the public interest." SEC v. United States Realty \& Improvement Co., 310 U.S. 434,455 (1940). 
A method of analysis which looks to whether the public interest would be furthered by granting the requested relief is not unknown in private antitrust litigation. In Maltz $v$. Sax, ${ }^{95}$ a treble-damage action in which a manufacturer of wagering punchboards alleged that several of his competitors had combined to prevent the sale of his product, the court dismissed the complaint on the grounds that the manufacture and sale of gambling devices was against the public interest and that the antitrust laws should not be used to protect an endeavor which is inimical to the public welfare.

However, in more complex situations than Maltz v. Sax, where the plaintiff's unlawful practices may involve only one element of an entire business venture, the courts are faced with a difficult task in determining whether the plaintiff's violations would be able to continue without the forced cooperation of the defendant. The resolution of the question demands a searching analysis of the facts of each case.

Many of the relevant considerations can be found in cases where the plaintiff requests the court to order the defendant to furnish the plaintiff with goods for resale. Assume, for example, a suit by a distributor of televisions to enjoin the leading manufacturers of television sets from boycotting him. If the defendants can show that the plaintiff is using the defendants' goods to force dealers to take other goods or will furnish the dealers with televisions only if they agree to certain restrictive practices, the policy of free competition would best be served by conditioning any injunctive relief for this plaintiff on the plaintiff's abandoning his unlawful restraints. If the court did not condition its injunction in this manner, the antitrust laws would be used to remove the only business restraint on a serious antitrust violation. This analysis suggests that Interborough ${ }^{96}$ was incorrectly decided. There, the court's dismissal of the unclean hands defense resulted in its ordering the defendants to cooperate with the plaintiff and furnish him with the goods necessary to perpetuate the monopoly over the distribution of magazines. ${ }^{97}$

If it is accepted that the courts should entertain, to a limited extent, defenses based upon the plaintiff's antitrust violations in actions for injunctive relief, the same defenses should also be applied in claims for treble damages, which are commonly joined with requests for injunctions..$^{98}$ If a court would accept the defense in a suit to compel the defendant

95134 F.2d 2 (7th Cir.), cert. denied, 319 U.S. 772 (1943). 1952).

96 Interborough News Co. v. Curtis Publishing Co., 108 F. Supp. 768 (S.D.N.Y.

o7 During the course of its opinion, the court expressed a public interest in "the free distribution of periodicals." Id. at 770 . It would seem that the order to furnish magazines to the plaintiff, without any restrictions on the use of the magazines, would enable the plaintiff to strengthen his monopoly over the distribution of magazines and thus defeat the public interest in the free distribution of magazines.

98 See, e.g., Hotel Phillips, Inc. v. Journeymen Barbers Union, 195 F. Supp. 664 (W.D. Mo. 1961), aff'd per curiam, 301 F.2d 443 (8th Cir. 1962) ; Interborough News Co. v. Curtis Publishing Co., 108 F. Supp. 768 (S.D.N.Y. 1952). 
to deal with the plaintiff while refusing to consider the plaintiff's misconduct in an action at law, the threat of treble-damage recoveries because of the refusal to deal would have the same practical effect as an injunction, and the defendant would be forced to deal with the plaintiff. This analysis was not accepted in Kiefer-Stewart, where the Supreme Court stated that the illegality of the plaintiff's conduct could not "legalize" the unlawful acts of the defendants.9 However, recognition of the defense does not purport to remove the stigma of illegality from the plaintiff's conduct; it simply recognizes that the proper remedy in the case may not be an award of treble damages to this plaintiff.

At the other extreme, where the plaintiff is engaged in a restraint of trade which is completely unrelated to the resale of goods of the defendant and which had been unaffected by the defendant's refusal to sell, the courts should not deny relief to the plaintiff. Thus, in the hypothetical suit by the television distributor, the court should not entertain a defense based upon the distributor's attempt to monopolize the television repair market. In cases falling between these two extremes it is difficult to determine whether the plaintiff could continue his unlawful conduct without obtaining judicial relief from the defendant's violations. If the plaintiff television distributor uses the defendants' goods as a component part of his own product, the courts may properly deny relief where the degree of public acceptance of the plaintiff's product substantially depends upon the presence of the defendants' goods. But where the defendants' products are used in the plaintiff's manufacturing process, it is more unlikely that the plaintiff would be forced to discontinue his restrictive practices if he does not obtain relief. Under this analysis, the decision in Trebuhs ${ }^{100}$ seems correct. In that case the plaintiffs' monopoly over the booking of legitimate plays was primarily based upon their ownership of the theaters, and the inability to obtain lower advertising rates did not substantially impair their ability to perpetuate the monopoly.

Even where the plaintiff and defendant are competitors, rather than buyer and seller, the courts may find that the plaintiff could not pursue his unlawful practices without obtaining relief against the defendant. In Affiliated Music Enterprises v. Sesac, Inc., ${ }^{101}$ an action for treble damages and an injunction, both plaintiff and defendant were engaged in the business of acquiring from the owners of copyrighted music the exclusive right to license the public performance of the copyrighted compositions. The plaintiff alleged that the defendant had pooled copyrights and revenues, imposed tie-ins, and fixed prices, thus acquiring a monopoly in certain parts of the music field. The defendant counterclaimed, asserting that

90 Kiefer-Stewart Co. v. Joseph E. Seagram \& Sons, 340 U.S. 211, 214 (1951). 1952).

100 Trebuhs Realty Co. v. News Syndicate Co., 107 F. Supp. 595 (S.D.N.Y.

101160 F. Supp. 865 (S.D.N.Y. 1958), aff'd, 268 F.2d 13 (2d Cir.), cert. denied, 361 U.S. 831 (1959). 
the plaintiff was engaging in the same practices in an attempt to replace defendant as the monopolist in the area. The court held the defendant's allegations to be well founded and dismissed the complaint. The court saw no public interest in replacing one monopoly with another, and stated that it would not place "its imprimatur on a scheme which involves . . . a violation of the antitrust laws." 102

\section{Conclusion}

If the courts' sophisticated approach to the "unclean hands" defense in the patent cases is used in antitrust actions for injunctive relief and treble damages, the courts could most effectively free the economy from anticompetitive activities. The courts should receive evidence which will enable them to ascertain the effect of their decrees and accept the "defense," not as a means of protecting a guilty defendant or punishing an equally guilty plaintiff, but as a method of restoring competition. Moreover, the exposure of plaintiffs' antitrust violations will bring to public awareness the anticompetitive activities of all parties involved in the action. The fear that such exposure will result in fewer private antitrust suits being brought before the courts seems overstated. Plaintiffs bring private actions for injunctive relief because they are being damaged by the restrictive activities of the defendants. Such plaintiffs need the help of the courts, and if they know that their own anticompetitive activities will be exposed, they will tend to cease their own violations.

Gerald J. McConomy

102160 F. Supp. at 876. 